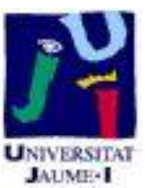

Título artículo / Títol article: Energy intensity and investment ownership across Chinese provinces

Autores / Autors

María Jesús Herrerías Talamantes, Ana María Cuadros Ramos, Vicente Orts Ríos

Revista:

Energy Economics, 2013, vol. 36

Versión / Versió:

Pre-print

Cita bibliográfica / Cita

Herrerías Talamantes, María Jesús ; Cuadros

bibliogràfica (ISO 690):

Ramos, Ana María ; Orts Ríos, Vicente. Energy

Economics, 2013, vol. 36, p. 286-298

url Repositori UJI:

http://hdl.handle.net/10234/91630 


\title{
Energy Intensity and Investment Ownership across Chinese Provinces
}

M.J. Herrerias*

\author{
A. Cuadros ${ }^{\dagger}$
}

\begin{abstract}
August 2012
Abstract

The main objective of this paper is to investigate whether openness and investment ownership are key factors in explaining the diffusion of energy-saving technologies in China. Compared with previous studies, the novel aspect of this work is the use of a rich dataset at provincial level, which allows the high level of regional heterogeneity to be taken into consideration. The unbalanced regional growth has been translated into differences in the need for energy resources across the vast territory of China. A detailed analysis of these issues may provide new insights into the energy situation in this country. The analysis is also disaggregated by type of energy: coal, electricity and petroleum. We estimate the models by panel-corrected standard errors, developed by Beck and Katz (1995), over the period 1985-2008. Results obtained confirm the hypothesis that both foreign and non-state investments play a leading role in the decline of energy intensity across Chinese regions, whereas there is no evidence of a positive contribution of state investment. The findings also reveal differences in energy intensity across regions, thus confirming the importance of accounting for the regional dimension when analyzing energy consumption in China.
\end{abstract}

Key words: Energy intensity, Chinese provinces, Investment ownership, FDI, Technology diffusion. JEL Classification: O24, Q4, 053, P28

Corresponding author: M.J. Herrerias, The University of Nottingham, School of Contemporary Chinese Studies, Jubilee Campus, NG8 1BB, Nottingham, The United Kingdom. E-mail address: maria.jesus herrerias@nottingham.ac.uk.

\footnotetext{
* The University of Nottingham, School of Contemporary Chinese Studies, Nottingham, The UK.

+ Universitat Jaume I. Department of Economics and Institute of International Economics. Campus Riu Sec, 12071 Castellón (Spain). Emails: cuadros@eco.uji.es and orts@eco.uji.es
} 


\section{Introduction}

Since the opening-up policy was implemented at the end of the 1970s, China has undergone a fast process of modernization and economic growth. Consistent with this performance, in 2009 China overtook the United States to become the world's largest energy user (IEA, 2010). However, this growth in the consumption of energy resources is a relatively recent phenomenon since, in 2000, Chinese energy use was only half that of the United States. The increase in China's energy consumption between 2000 and 2008 was more than four times higher than in the previous decade. The projections of this growth remain strong due the current lower per-capita consumption compared to other countries and the size of the population. Thus, a detailed analysis of the energy sector in this economy may provide new insights into the current debate in the energyeconomics literature. Firstly, because China is an energy-dependent economy (Yuan et al., 2008). Secondly, its large demand for energy resources and its possible repercussions on climate change have drawn greater attention from scholars and policymakers because of its implications in both the domestic economy and international markets. Finally, energy-saving measures to protect the environment undertaken in China will have a significant influence on the global effort to reduce energy demand.

In the case of China, the most important debate on energy aspects during the last two decades has been focused on the causes of the decrease in energy intensity ${ }^{1}$ (see Figure 1). Indeed, energy intensity has fallen since 1978, coinciding with the introduction of market-oriented and open-door reforms ${ }^{2}$. Furthermore, as has been pointed out by Fan et al (2007), since China accelerated its market oriented economic reforms at the end of 1992, its energy intensity has declined 3.6\% annually over 19932005. These authors concluded that the accelerated marketization contributes substantially to energy efficiency improvements since 1993. Fisher-Vanden et al. (2006) claimed that these reforms can lead to lower energy intensity in two ways. On the one hand, reforms may result in changes in industrial composition. Opening up to international trade has altered the relative profitability of certain industries particularly heavy industry - which would explain the gradual move away from energy-intensive heavy industries (structural change). On the other hand, market reforms may also lead to energy-saving innovations, thus raising energy productivity at the firm level (technological progress).

There seems to be general agreement in the relevant literature about the key role played by technological progress in explaining China's declining energy intensity, although the role played by structural change remains a controversial issue (Zhang, 2003; Fisher-Vanden et al., 2004; Liao et al., 2007 and Ma and Stern, 2008). However,

\footnotetext{
${ }^{1}$ This variable refers to the amount of energy consumed relative to GDP.

2 However, it should be noticed that the decreasing trend in energy intensity has not been constant during the analyzed period (see Zhao et al, 2010 and IEA, 2007).
} 
most studies failed to identify the channels through which technological progress has caused the decline in energy intensity. Moreover, although energy efficiency rose during the 1980s, China's overall energy efficiency in 1990 continued to lag behind that of other countries with similar levels of per-capita income (Fisher-Vanden et al., 2004). Hence, there is much room for improvement and development in China's energy situation.

The main objective of this paper is to investigate whether reforms undertaken by China since 1979 have been a significant driving force in the diffusion of energy-saving technologies and, in turn, in reducing the energy intensity. We focus on both openness and reforms to investment ownership. On the one hand, both openness to Foreign Direct Investment (FDI) and imports have been widely recognized by the literature as key mechanisms for the diffusion of technology. Foreign ownership has been regarded as a major vehicle for the transfer of advanced technology from developed to developing countries. China is a particularly interesting case to study due to the role played by technology transfer via FDI. Since opening up its economy in 1979, China has absorbed an increasing amount of FDI and is now among the world's largest hosts of FDI inflows. Imports of machinery and equipment are another important channel for improving the efficiency of domestic production due to the technology embodied in these goods. ${ }^{3}$ It is well known that China has developed its innovation strategy by combining imports of technology with domestic research and development. In this strategy, technology spillovers coming from FDI seem to be more significant than those of imports. ${ }^{4}$

On the other hand, reforms to investment ownership within China have included a rapid expansion of various ownership classifications outside the state sector, both through new entry and through the conversion of state-owned enterprises (see FisherVanden et al., 2004). Despite the rapid growth of foreign investment and non-state investment activities, state ownership still represents the major share in physical capital (see Luo, 2007, and Li, 2009). Wholly foreign-owned firms are uncommon in China; most firms are joint ventures between local (frequently state-owned) and foreign enterprises (see Harrison and Rodriguez-Clare, 2010). The promotion of joint ventures has been the core of China's policy to benefit from inward investment. Over a certain period, China required joint venture as a condition for FDI inflows. The goal was to create linkages between foreign and local firms (see Fu et al., 2011). Girma et al. (2009) highlight the fact that foreign capital participation in state-owned enterprises is associated with higher innovative activity.

An additional feature to be considered in the case of China is regional heterogeneity. There are several reasons for considering the regional dimension in the

\footnotetext{
${ }^{3}$ For a recent survey about the channels through which international technology is spread, see Keller (2004).

${ }^{4}$ See Lai et al. (2006).
} 
case of this country. Firstly, the varying stages of development of coastal and inland provinces have been translated into differences in the need for energy resources, the former being the ones that require more energy, compared to central and western provinces (see Fisher-Vanden et al., 2004). Secondly, due to preferential policies (special economic zones), FDI has often been concentrated along the coast (see Figure 2). Thirdly, the high level of heterogeneity across Chinese regions also refers to the distribution of resources. These are unevenly distributed across regions, the producers being located in the North and South of China, while the consumers are to found mostly on the coast. Moreover, there are important deficiencies in energy transportation. Regions that produce electricity or coal distribute their resources to other more developed regions through the upgraded transmission grid and the three main corridors in the North, Central and South regions. ${ }^{5}$ Due to the large distances between regions, the characteristics of the transmission grid are of great interest because of its possible influence on improving the use of energy. Finally, although the central government has repeatedly stressed the importance of upgrading the quality of economic growth with energy-saving, local authorities have not really managed to implement it. In energy, as in other economic fields in China, this is one of the controversies between the local and central governments, which makes it difficult to implement economic reforms. ${ }^{6}$

In spite of the importance of regional heterogeneity within China and its influence on overall energy intensity, most studies on this country do not take this question into consideration. Following the above arguments, these analyses can be misleading. In this paper, we contemplate the influence of heterogeneity by considering both the interprovincial energy grids as well as the official partition of regions in this country (coast, central and west). Specifically, we employ a macro-level panel data set which includes 28 regions over the period 1985-2008. We use Beck and Katz's (1995) estimator to allow for the aforementioned heterogeneity and the correlation that may exist across different regions. In addition to investment ownership, and to rule out spurious results, we have also accounted for the more relevant factors used by the empirical literature to explain the decrease in energy intensity in this country, such as energy prices, the share of industry over GDP and imports. Moreover, by considering the concentration of certain types of energy in particular regions, we differentiate the source of energy use into total, coal, electricity, and crude oil. This allows us to determine with greater precision the effect of potential candidates for reducing the use of energy per unit of output.

Compared with previous studies that examine energy intensity in China, there are several novel aspects in this work. First, to the best of our knowledge, there is no

\footnotetext{
${ }^{5}$ One of the causes of this inefficiency is that the transmission grid is operating independently in these corridors. The Chinese government has stated that by 2020 they will operate in a unified system, thereby improving the levels of energy efficiency.

${ }^{6}$ See Zhou et al. (2010) and Liao et al. (2007).
} 
previous empirical evidence based on statistical inference that has made use of provincial data for this country. ${ }^{7}$ Second, there is no evidence on energy efficiency that takes into account the composition of energy resources in terms of coal, electricity and petroleum and by analyzing all these sources of energy may provide new insights and a complete picture to the current debate. ${ }^{8}$ Third, we examine the influence of both openness (FDI and imports) and the pattern of investment ownership in China (foreign versus domestic, state versus non-state). Finally, we examine the specific investments in the energy sector. In this sense, our study may provide new insights into the analysis of those factors that play a greater role in improving energy efficiency in China. This is a relevant topic due to the extraordinary role of China in the world economy and for the challenge posed by energy and climate.

The rest of the paper is organized as follows. Section 2 focuses on the literature review. Section 3 covers data and methodological issues. In section 4 we report the empirical results. Our conclusions are discussed in Section 5.

\section{Literature Review}

One of the main conclusions of the Copenhagen conference on climate change in 2009 was the need to support developing countries in employing energy-saving technologies. ${ }^{9}$ Technology diffusion can be a key to improve energy efficiency. Despite the relevance of this issue, relatively little research has been carried out on the transfer of energy-saving technologies to developing economies. However, a better understanding of these mechanisms is important to achieve energy efficiency gains and improve the quality of the environment worldwide.

Keller (2004) provides an overview on how international technology transfer occurs through the process of openness. Imports are an indicator for the integration of a country in world markets and a major channel for technology transfer. Technology is embodied in capital and intermediate goods, and so direct importation of these goods is one channel of transmission (see Caselli and Wilson, 2004, and Eaton and Kortum, 2001). These imports create productivity spillovers via imitation of the imported goods and via improved application methods adopted together with the imported goods (Hübler, 2011; Herrerias and Orts, 2011).

The role played by multinational companies in the transmission of new technologies to host countries has also been widely recognized by the literature. They tend to be

\footnotetext{
${ }^{7} \mathrm{Wu}$ and $\mathrm{Li}$ (1995) analyzed the regional dimension, but their work was based on a descriptive analysis. By contrast, Ito et al. (2010) made statistical inferences about the regional energy demand, without considering the scope of this paper.

8 For example, Zhang and Wang (2008) analyzed energy-saving technologies and productive efficiency in the Chinese iron and steel sector.

${ }^{9}$ Developing countries, whose economies and populations are growing fastest, contribute $74 \%$ of the increase in global primary energy use in the Reference Scenario between 2005 and 2030. China and India alone account for $45 \%$ of this increase (IEA, 2007).
} 
larger and more technologically intensive than firms in the host countries, and this might be the reason why they are good at sourcing technology (Keller, 2004). Several studies highlight the fact that FDI inflows contribute to increase the existing level of knowledge through labor training, skills acquisition, and the introduction of alternative management practices as well as new inputs and technologies (see Cuadros et al., 2004; Blalock and Gertler, 2008; Kugler, 2006; Kemeny, 2010, and Alguacil et al., 2011). For China, Liu (2008) confirms the existence of technology spillovers from FDI in the manufacturing sector. Using panel data for 29 provinces between 1987 and 2001, Luo (2007) concludes that neither the state sector nor the private sector made any contribution to the improvement of technical efficiency. Only FDI exerts a significant positive effect on total factor productivity.

In general, there is no reason to believe that energy technologies diffuse in a different way to other technologies. Energy-saving characteristics usually diffuse jointly with other technologies, since the former are connected to other technological advances in the same product (see Hübler, 2009 and Hübler, 2011). However, only a few studies specifically examine the influence of trade and FDI on the diffusion of technologies that affect energy-efficiency in the destination country (see Cole, 2006, and Peterson, 2008).

On the aggregate level, Mielnik and Goldemberg (2002) carried out a standard Ordinary Least Square (OLS) regression analysis for 20 developing countries for the years 1987 to 1998 and concluded that FDI reduces energy intensity. Hübler and Keller (2010) considered that these results were likely to be spurious, since the authors did not control for other influences on energy demand. In an attempt to overcome these shortcomings, Hübler and Keller (2010) applied panel-estimation techniques for a sample of 60 developing countries (including China) during the period 1975-2004. These authors highlighted the fact that raising trade and FDI flows may reduce energy use in the destination country by a composition and technique effect. The composition effect reduces a country's energy use if the economy specializes in sectors with lower energy intensity. But, at the same time, as countries develop, the sectoral change shifts economic activity from the agricultural to the industrial sector. Since the latter is more energy-intensive, this implies a positive composition effect. Thus, the sign of the composition effect is not clear. In the case of China, industry accounts for approximately $70 \%$ of the total energy consumption, so this is the largest energyconsuming and end-use sector (see Zhou et al., 2010, and Liao et al., 2007). Therefore, as has been argued by Fisher-Vanden et al. (2004), sectorial changes can be important to explain the decline in energy intensity. However, most previous studies have found sectoral shift to be a relatively small contributor to the decline in China's energy intensity (Garbaccio et al., 1999; Liao et al., 2007, and Ma and Stern, 2008). ${ }^{10}$

\footnotetext{
${ }^{10}$ Following Ma and Stern (2008), the actual changes in industrial structure were very different in the 1980s and the period following the 1980s. From 1980 to 1990, structural change occurred
} 
The technique effect covers the impact of openness on the implementation of less energy-intensive technologies or the adoption of better managerial practices that have an energy-reducing effect. It is commonly assumed that the technology used by foreign investors is superior to the technology that is currently in place in developing countries. The results obtained by Hübler (2009), by calibrating a Computable General Equilibrium model in China, indicate that FDI and trade both induced energy efficiency gains in this country and should not be neglected in climate policy analyses. Furthermore, Lai et al. (2006), with a different approach, found that the technology spillover effects of FDI in China seem to be more significant than those of imports. These authors concluded that foreign firms not only provide imitation and learning opportunities for indigenous ones by demonstration effects, but also indirectly improve the product quality and variety of its backward or forward firms by industrial linkages. These authors highlight the fact that foreign firms play a key role in China's imports, especially for high-tech goods imports, and therefore there is a complementary relationship between imports and FDI in terms of technology spillovers. More recently, however, Hübler and Keller (2010) do not confirm any significant effect of FDI on energy intensity for the sample analyzed.

Kumar (2003) and Sahu and Narayama (2009) highlight the fact that the type of ownership may also have an important influence on energy intensity. The results obtained for India indicate that foreign ownership is associated with lower energy intensity while state ownership is found to be associated with higher energy intensity. The hypothesis that foreign companies are more efficient in the use of energy than their domestic counterparts has been confirmed by studies based on firm-level data. Eskeland and Harrison (2003) found a negative effect of FDI on energy intensity for manufacturing plants in Côte d'Ivoire, Mexico and Venezuela. Fisher-Vanden et al. (2004, 2006) found that foreign-invested firms in China are consistently more energy efficient than their state-owned counterparts. Although the proportion of the stateowned economy has decreased over time, it is still the main driving force in the total fixed investment to date. Their analysis was carried out for a relatively short time period (1997-1999) for a sample of 2500 large and medium-sized industrial enterprises. They found that changing energy prices and research and development expenditures are significant drivers of declining energy intensity, whereas changes in ownership, region and structural change are less important. Sinton and Fridley (2000) conclude that the shift from state-owned to collective, private and foreign invested ownership plays and important role in improving energy efficiency since 1996 in China. To the best of our knowledge, Fisher-Vanden et al and Sinton and Fridely (2000)'s papers are

mainly from primary industry to services. In this period, the share of secondary industry was relatively constant. However, from 1990 to 2003, a shift in output from primary to secondary industry dominated. 
the only ones that refer to investment ownership as one of the factors that might influence energy intensity in China.

Although China's declining energy intensity is often explained in terms of technological and sectoral factors, another important question to be taken into account is the role played by energy price deregulation. With the initiation of China's "twotiered pricing system" in 1984, prices set by the central plan have been gradually replaced with market-mediated prices. The elimination of state-set prices has led to rising relative energy prices, which may be inducing energy-saving innovations (Fisher-Vanden, 2004). ${ }^{11}$

Broadly speaking, explanations for China's decline in energy intensity fall into three categories. The first one refers to gains in energy efficiency associated with the investment process, which operates through the incorporation of new energy-saving technologies. The second possible explanation centers on sectoral change involving a decline in the relative weight of China's energy-intensive sectors. The third one is focused on the role played by energy prices. In this paper, we attempt to measure the relative contribution of all these factors. The main novelties of our analysis are related to the use of disaggregate data by provinces and type of energy, and the examination of the role played by market reforms on energy efficiency in China.

\section{Data and Methodology}

\subsection{Data}

This paper attempts to unravel the main factors that have influenced the reduction in energy intensity in China. To carry out the analysis, we disaggregate total energy intensity (defined as total energy consumption/GDP) ${ }^{12}$ into coal, electricity and petroleum (also expressed in intensities). We introduce imports, the share of industry (both expressed as share of GDP) and energy prices as control variables in all our estimations. Imports are included to isolate the influence of FDI from other channels of international technology transfer. The share of industry to GDP is related to the aforementioned composition effect, while prices are also considered to be an important candidate in accounting for the decline in energy intensity. ${ }^{13}$ However, energy price data for each region is difficult to obtain since, in many cases, the data available start in 2003 (which is almost the final part of our sample). The same difficulty arises when it

${ }^{11}$ It is important to mention that the price of coal has been liberalized; electricity prices, however, still depend on the government.

${ }^{12}$ With this definition, we are accounting for much of the potential scale effect. Only if the effect of increases in economic activity on energy use was biased, this would lead to specification problems (see Hübler and Keller, 2010). Nevertheless, empirically, the scale effect remains surprisingly weak in relation to the technique effect, as has been pointed out by Anteweiller, Copeland and Taylor, (2001).

${ }^{13}$ A detailed description of the variables used in this paper appears in the data appendix. 
comes to differentiating the price for each source of energy. Given these limitations, we use the crude oil price as a proxy variable for energy price. ${ }^{14}$ We assume that increases in crude oil price probably lead to increases in domestic prices of energy, so both magnitudes should be correlated. In addition, to investigate the effect of investment ownership on energy intensity we differentiate between both domestic versus foreign investment as well as state versus non-state investment. We go further still into the analysis by examining the effects of investment ownership in each region and for each type of energy considered in this work (coal, electricity and petroleum). Finally, we analyze the impact of the differentiation between state and non-state investment in the energy sector. In this work, we use annual data in the case of 28 Chinese regions ${ }^{15}$ from 1985 to 2008 from Energy Statistical Yearbook and Statistical Yearbook, both from National Bureau of Statistics of China (see appendix). This panel data is unbalanced.

The spatial or regional dimension has been captured by including data from the aforementioned 28 regions of China. Additionally, to examine whether there are significant differences between areas, we present the results for two types of regional groupings - the transmission grid and the administrative division of provinces (among the East, Central and Western zones). Although there is a transmission grid for each type of energy, they are quite similar to each other. Thus, the coal transmission grid was used in the analysis, since this is the most important source of energy in China. This indicator may capture some of the spatial differences, as well as the discrepancies between national and regional economic policies on energy intensity, in greater detail than the administrative division of regions. Thus, as it is possible to see in the Appendix, we create a dummy variable for each of the transmission grids. In a second stage, we create an interaction effect between each of the six transmission grids and each type of investment ownership to account for the differential effect of investment ownership on each area considered.

Figure 3 shows the evolution of energy intensity for coal and electricity throughout the Chinese regions during the period 1995-2008. This figure (along with Figure 1) allows us to observe the decrease in energy intensity over time as well as its singular distribution across regions and sources of energy. As we can see, there are relevant differences between inland and coastal areas. We can also appreciate the different levels of energy efficiency between coal and electricity. Moreover, in Table 1, we report

${ }^{14}$ The World Bank assigns the following weights for calculating the index of energy price: Coal $(4.7 \%)$, Crude Oil (84.6\%) and Natural Gas $(10,8 \%)$. Therefore, we consider that, in absence of the exact prices for energy, using the price of Crude Oil as a proxy seems to be most appropriate.

${ }^{15}$ In China there are 31 regions. However, as other studies did, Chongqing is included in Sichuan and Hainan in Guangdong due the independence. This is the normal practice in Chinese studies. Tibet is excluded for the lack of data. Besides, given some software limitation missing values were fixed to zero in the maps in the appendix. It is the only way to draw the map with all regions. 
a summary of statistics on the role played by investment ownership, where it can be seen that state investment still plays the major role.

\subsection{Methodology}

The notable variability across regions and over time are captured by individual and time effects through the application of panel-data techniques. However, it is wellknown that OLS estimates are bias by the omission of these two aspects in panel data approach. Thus, our empirical strategy was focused on a set of estimators that introduced these two features in the model specification. The first candidate was the fixed effect and random effects estimators. We run the regressions for all models, and Hausman test indicated that fixed effect estimator is preferable than random effects since individual characteristics of Chinese regions are significant in the analysis. We test further for the presence of endogeneity problems in our models, however, it was not found any symptom of this aspect in the specification, therefore being unnecessary the use of instrumental variables. However, we detected through the serial correlation and heterocedasticity tests that both are present in the model. So, fixed effect estimator can cause bias in the estimates. So, we need to search among other candidates another estimator that considers the desirable properties that fixed effects estimator has, but at the same time that takes into account the serial correlation and heterocedasticity to provide robust, consistent and efficient estimates. ${ }^{16}$

In sense, one of the feasible solutions to overcome this problem is to use the method proposed by Beck and Katz (1995), i.e., the so-called panel-corrected standard errors (PCSE). The attractiveness of this approach, according to these authors, is that common techniques applied to time-series cross-section (TSCS) data produce incorrect results, in particular with regard to the accuracy of standard errors. Furthermore, unlike other methods used in the previous literature, like input-occupancy-output structural decomposition analysis or the Divisia Index (Ma et al., 2010), our method makes it possible to test the hypothesis of interest while also taking into consideration the high degree of heterogeneity across Chinese regions. Other researchers, like Hübler (2011), use the Computable General Equilibrium model to obtain their results. However, our method does not impose any assumptions on the possible values of the coefficients and relies on more flexible hypotheses.

One of the advantages of PCSE is that it overcomes the well-known problem from OLS estimates in panel-data techniques, when one or more Markov assumptions are not satisfied. Initially, PCSE comes from an earlier work by Parks (1967), where the presence of temporal and spatial correlation in the error term as well as heteroskedasticity is explicitly taken into account and is estimated by Generalized Least Squares (GLS). However, the use of this method can lead to dramatic

${ }^{16}$ Due the short period of time considered in this work the dynamics of the model are not investigated. 
underestimates of parameter variability in the common research, due to the assumptions made on the structure of the error term. The alternative, often used by researchers, is to apply Feasible Generalized Least Squares (FGLS), which relaxes the assumption of known errors structure and uses an estimate of the error process. However, this method is not free from criticism because when there are a large number of parameters to estimate, FGLS underestimates the standard errors of the coefficients between 50\% and 300\%, according to Monte Carlo simulations (Beck and Katz, 1995). Knowing these drawbacks, Beck and Katz (1995) proposed some modifications on Parks' estimator in the formula for the sampling variability of the OLS estimates, which make more efficient estimates. ${ }^{17}$

Thus, following Beck and Katz's approach, the standard formulation of Time Series Cross-Sectional (TSCS) models under the assumption of poolability is as follows: ${ }^{18}$

$$
\begin{gathered}
y_{i t}=X_{i t} \beta+\lambda_{i}+\gamma_{t}+\epsilon_{i t} i=1, \ldots N_{i} t=1 \ldots T \\
\epsilon_{i, t}=\rho_{i} \epsilon_{i, t-1}+v_{i, t}
\end{gathered}
$$

where $\boldsymbol{X}_{i \mathrm{t}}$ is a vector of $k$ exogenous variables (investment ownership, imports, sectoral composition, prices) and observations are indexed both by provinces $(i)$ and by time $(t)$. $y_{i t}$ denotes the vector of observations on the dependent variable and, $\lambda$ and $\gamma$ are the individual and time effects respectively. We assume that the data are stacked by provinces. The covariance matrix of the errors (NT $x$ NT) has the common element $E\left(e_{i, t} e_{j, a}\right)$ by $\Omega \cdot v_{i, t}$ is the error term independently distributed across time, while $\rho_{i}$ indicates the first-order serial correlation that, given our small sample, we have set as common for all the regions $\left(\rho_{i}=\rho\right)$.

\section{Discussion of the results}

In Table 2, we report results from the specification that distinguishes between foreign and domestic investment as sources of potential reductions in energy intensity, whereas Tables 3 and 4 focus on the decomposition of total investment in state and non-state investment and on investment in the energy sector, respectively. In all these specifications we control for the additional factors that may influence energy efficiency, such as openness to imports, the share of industry and energy prices. The effect of the main variable of interest in each table is split into the different transmission grids and the official partition of Chinese provinces into three regions. The first three columns of

\footnotetext{
${ }^{17}$ See Beck and Katz (1995) for technical details.

${ }^{18}$ Given the short sample in our data, the issue of heterogeneity in the beta coefficient is not considered. In addition, we only contemplate the static version of panel data for the same reason.
} 
the tables report the results for "Total Energy Intensity" while the others show the findings for "Coal", "Electricity", and "Petroleum".

As can be seen in Table 2, openness has undoubtedly been a driving force in the reduction of energy intensity. The coefficients of both imports and FDI are always negative and significant regardless of the specification of the model and the source of energy considered. ${ }^{19}$ This result is analogous to that found by Kumar (2003) and Sahu and Narayama $(2009)$ for India, by Fisher-Vanden et al. $(2004,2006)$ for a sample of firms in China or by Eskeland and Harrison (2003) for manufacturing plants in Côte d'Ivoire, Mexico and Venezuela. These findings would confirm the idea that foreigninvested firms use more energy-efficient technologies, and that access to foreign technologies has been a relevant factor in the reduction of energy intensity in China. The regulatory pressures in the developed parent country of multinationals investing in China probably explain the use of cleaner technologies by these firms. Moreover, the fact that exports to developed countries represent a significant share of the sales of these companies forces their affiliates to meet the stringent environmental standards of export markets for their Chinese manufactured products.

Nevertheless, when we account for regional heterogeneity, our results show a differential impact of foreign investment in the different regional classifications considered. If we focus on the traditional administrative division, we can observe that in the East area, which includes those provinces that have received the highest amount of FDI, ${ }^{20}$ foreign ownership has had a negative effect on energy intensity (both in total energy intensity as well as in coal and electricity). Thus, there seems to be a positive relationship between the magnitude of inward FDI and the reduction of energy intensity. A similar pattern is observed when we use the grid classification. The main provinces receiving FDI are those included in Grids 2 and 3. Here again, FDI reduces energy intensity both in total energy and in the different sources of energy considered (the only exception being electricity in Grid 221). By contrast, Grids 1 and 4, as well as the Central region, account for the majority of provinces that have received low or virtually no FDI inflows. In these cases, we cannot find any significant role of FDI in energy efficiency gains. The only partially unexpected result is the negative impact of FDI on energy intensity in Grids 5 and 6 (to a lesser extent) as well as in the West region, since these areas have not usually been recipients of FDI. However, there are

19 There is only one exception in the case of the role played by FDI in energy intensity for petroleum. This finding probably accounts for the fact that very high monopoly exists in China's petroleum industry. Only three state-owned enterprises have rights to exploit oil, so it is very difficult for foreign investors to access.

${ }^{20}$ The East region includes the largest recipients of FDI, such as Beijing, Tianjin, and Shanghai (the urban area), and Shandong, Jiangsu, Zhejiang, Fujian, and Guangdong (the coastal industrialized area).

${ }^{21}$ This result can probably be explained by the fact that the coal industry has been liberalized from the government, but electricity is still run by the national authority and also for the fact that non-state investment is smaller compared with state-investment as shown in Table 1. 
some notable exceptions that could partly explain this result. This is the case of Guangdong province (traditionally a recipient of large inflows of foreign investment), included in Grid 5, and the province of Sichuan (which is becoming a relevant destination of FDI) and is included in the Western region.

One novelty in our estimations is the finding that domestic investment was also a significant source of improvement in energy efficiency during the period considered. Table 2 shows that this variable is always negative and very significant, not only for total energy intensity but also for all sources of energy considered. This result could be reflecting either the influence of domestic innovation or the interaction between the national and foreign innovation processes with regard to energy saving. ${ }^{22}$ FisherVanden et al. (2006) showed that, from 1997 to 2001, the internal share of technology development expenditures by total industry was $67 \%$, while imported technology expenditures represented the remaining $33 \%$.

Table 3 reports our results for the decomposition of the total investment in state and non-state investment. From this table it follows that the pattern of investment ownership in China has also played a leading role in the reduction of energy intensity. As can be seen in the first two rows of Table 3, non-state investment has a negative and significant impact on energy use (with the only exception of electricity ${ }^{23}$ ). ${ }^{24}$ In contrast, state-investment has a positive and always significant effect on energy consumption. Overall, these findings could be reflecting the specific nature of state investment in China which mainly focus on infrastructure construction such as railways, and energy intensive industries of which energy intensity is relatively higher. In fact, stateinvestment has been mainly located in some energy-intensive industries which the non-state firms are hard to access to. Moreover, it is likely that the technological changes induced by the state-investment may have been offset by the quick expansion of energy-intensive industries. ${ }^{25}$

The above pattern basically holds in the traditional provincial aggregation by regions, especially as far as state investment is concerned (in the case of non-state investment there are some parameters that are not significant). However, details offered by the higher level of disaggregation that provides the grid classification show that state investment does not play this role in all the provinces considered. Firstly, neither of these variables is significant in the case of electricity, with the exception of Grids 3 and 5. These grids present a negative and significant parameter in the stateinvestment variable. Secondly, the same negative result is obtained for total energy and coal in Grid 3 and for electricity in Grid 5. These results could be explained by taking into account two factors. First, the provinces included in Grid 3 account for a

\footnotetext{
${ }^{22}$ Investment promotion has been a key aspect in all economic plans implemented by the Chinese government since 1952.

${ }^{23}$ This result is also probably related with the comment in footnote 20.

${ }^{24}$ These results are similar to the ones obtained by Sinton and Fridley (2000).

${ }^{25}$ Thanks to the referee for this suggestion.
} 
significant proportion of inward FDI and Grid 5 contains Guangdong. Second, the most usual way of entry of foreign investment has been through joint ventures with state-owned enterprises. As has been pointed out by Nolan and Wang (1999), these firms might enhance their efficiency levels by their association with foreign enterprises.

We have also focused on investment in the energy sector by distinguishing between state and non-state investment. Table 4 confirms the fact that non-state investment has a negative and very significant sign. This is the clearest and strongest finding in this case. This result holds at the aggregate level, as well as in both regional classifications and for all energy sources. However, state investment in the energy sector has only reduced energy intensity in electricity but has increased energy use in coal and petroleum. The regional analysis in this case shows a positive and significant effect in the North and Northeast (Grids 1 and 2) and a reduction in energy intensity in Grid 3. Taken together, our findings indicate that the impact of state investment on the energy sector can be characterized as ambiguous.

The above-mentioned results suggest that reforms carried out by China since the end of 1970s, especially those focused on openness and changes in the patterns of investment ownership are relevant in explaining the reduction in energy intensity in China. These results give support to the so-called technique effect, that is, the impact of openness on the implementation of energy-saving technologies and better managerial practices.

Structural change also seems to have played the expected role, leading to a positive effect in energy intensity. However, this effect is not always significant in the case of total energy. This result could be explained by the ambiguity obtained in the case of coal, whereas in electricity and petroleum the expected positive sign is always obtained. As can be seen in Tables 2 and 3, increases in the share of industry in GDP reduce coal energy intensity, although this effect is only significant in some of the specifications. Following Ma and Stern (2008), inter-fuel substitution (among coal, oil, natural gas, electricity and other fuels) is found to contribute little to the changes in the energy intensity. Since this factor does not seem to be relevant in explaining this effect, it is possible that structural changes inside the industry sector can offer the explanation. As has been mentioned in Section 2, from 1990 to 2003, although the share of secondary industry increased from $36 \%$ to $53 \%$, there was a gradual move away from heavy industry. Therefore, the consequent increase in light industry during our period of analysis could help to explain the results obtained. A similar effect would occur if during the period in question had been significant improvements in relative energy efficiency of heavy industry. Also in this case may appear some ambiguity in the sign of this variable. ${ }^{26}$

\footnotetext{
${ }^{26}$ These explanations may also help to account for the ambiguous evidence on the role played by structural change obtained in other works (Zhang, 2003; Fisher-Vanden et al., 2004; Liao et al., 2007 and Ma and Stern, 2008).
} 
Finally, as can be seen in Tables 2, 3 and 4, energy price deregulation has been a relevant and significant factor in the reduction of energy intensity, regardless of the specification of the model and the source of energy. With the initiation of China's "two-tiered pricing system" in 1984, prices set by the central plan have been gradually replaced with market-mediated prices. This process has led to an increase in energy prices, forcing a significant reduction in energy use. This finding confirms, at the aggregate level and for a larger period of time, the results previously obtained by Fisher-Vanden (2004) for a sample of firms and for a very short period of time (19971999).

\section{Conclusions and Policy Implications}

One of the most important debates in the energy-economics literature has been focused on the causes behind the observed decline in energy intensity in developed countries. Among the relevant factors, it seems that technological progress has played an important role over the last two decades. This issue has started to receive a notable amount of attention in developing countries and, particularly, in fast-growing economies such as China. The analysis of energy-efficiency policies in the Chinese economy has relevant implications for its domestic economy as well as for the rest of the world.

Although there is some evidence to support the promotion of technological progress in order to achieve energy targets, most empirical works do not clarify the mechanisms that can improve energy efficiency, and offer little help in the design of energy-saving measures. This paper attempts to offer new insights into the specific factors that have driven the decline of energy intensity in China. We have focused on openness and changes in investment ownership. Consideration of the singularities of these factors in the case of China are expected to provide additional information for the energy intensity debate and a more complete picture of the channels that facilitate the reduction of energy intensity. Additionally, the results obtained may be helpful to policymakers in the design of energy policies in this country.

As we have emphasized throughout the paper, the regional dimension is essential to understand the current energy situation in China. Thus, we focus our analysis across the 28 Chinese provinces from 1985 to 2008 by using panel-data techniques. Specifically, we use panel-corrected standard errors, which allow us to consider the well-known heterogeneity both across regions and over time.

The findings of this paper indicate that the reforms focused on openness both to FDI and to imports have improved energy efficiency in China. Given the distance that still exists between China and developed countries in energy-saving technologies, this openness strategy should be continued. Additionally, in spite of its low magnitude, the increasing role of non-state investment appears as an important mechanism in the reduction of energy intensity, whereas state investment seems to be a more ineffective 
way of improving energy efficiency, with the exception of some areas in the Southeast, which have been the main receptors of FDI. This exception probably reflects the importance of joint ventures between foreign and state companies in the transmission of energy-saving technologies.

The results outlined above are largely confirmed when we consider investment in the energy sector. In this case, however, the clearest result is the positive and very significant contribution of non-state investment in reducing energy intensity. No matter what sources of energy or regional classifications are considered, the relationship between non-state investment in the energy sector and energy intensity is negative.

The ambiguous result associated to the role played by structural change in some cases probably reflects the differential impact between coal (where we find a decrease in energy intensity) and other energy sources (electricity and petroleum). This finding seems to be related to changes in the industrial composition, with a higher presence of light industry. This is a good new considering that industry is the leading sector in the Chinese economic performance.

The more detailed information offered by the transmission grid classification reveals the importance of considering regional heterogeneity in the analysis of energy intensity in China. We have detected differences both in the contribution of grids to the reduction of energy intensity as well as in the source of energy used. This is likely to be because they are operating independently from each other, thereby creating some inefficiency in the system. The Chinese government has stated the need to unify the power transmission grid by 2020. Although this may require a large investment effort, the interconnections among grids should be undertaken as soon as possible.

Finally, although it is possible to observe some advances in the price of energy as an important factor in reducing energy intensity, more effort is needed to operate fully under market mechanisms with greater transparency in order to improve the efficiency in this sector.

\section{Acknowledgements}

M.J. Herrerias gratefully acknowledges the financial support of European Union project No. 218246. A. Cuadros and V. Orts also gratefully acknowledge the financial support from the Spanish Ministerio de Ciencia e Innovación (ECO2011-28155), Generalitat Valenciana (PROMETEO/2009/068) and Pla de Promoció de la Investigació Fundació Caixa CastellóBancaixa (P1.1A2010-05 and P1.1B2010-17). The authors also wish to thank Qiao Yongyuan for all his help. Comments from participants at the CEA-UK/Europe Conference in London (April 2012) as well as from two anonymous referees are also acknowledged. The usual disclaimer applies. 


\section{References}

Alguacil, M., Cuadros, A. and Orts, V. 2011. Inward FDI and growth: The role of macroeconomic and institutional environment, J Policy Model 33, 481-496.

Antweiler, W., Copeland, B. and Taylor, M. 2001. Is Free Trade Good for the Environment? Am. Econ. Rev. 91, 877-908.

Beck, N. and Katz, J. 1995. What to do and not to do with Time-Series Cross-Section Data, Am Polit Sci Rev 89, 634-647.

Blalock, G. and Gertler, P. 2008. Welfare Gains from Foreign Direct Investment through Technology Transfer to Local Suppliers. J Int Econ 74, 402-421.

Caselli, F. and Wison, D. 2004. Importing Technology, J Monetary Econ 51, 1-32.

Cole, M.A. 2006. Does trade liberalization increase national energy use? Econ Lett 92, 108112

Cuadros, A., Orts, V. and Alguacil, M. 2004. Openness and Growth: Re-Examining Foreign Direct Investment, Trade and Output Linkages in Latin America, J Dev Stud 40, 167-192.

Eatom, J. and Kortum, S. 2001. Trade in capital goods, Eur Econ Rev 45, 1195-235.

Eskeland, G. and Harrison, A. 2003. Moving to greener pastures? Multinational and the pollution haven hypothesis. J Dev Econ 70, 1-23.

Fan, Y., Liao, H. and Wei, Y. 2007. Can Market Oriented Economic Reforms Contribute to Energy Efficiency Improvement? Evidence from China. Energ Policy 35, 2287-2295.

Fisher-Vanden, K., Jefferson, G. Liu, H. and Tao, Q. 2004. What is driving China's decline in energy intensity? Resour Energy Econ 26, 77-97.

Fisher-Vanden, K., Jefferson, M. Jingkui, and Jiangy, X. 2006. Technology development and energy productivity in China, Energ Econ 28, 690-705.

Fu, X., Pietrobelli, C. and Soete, L. 2011: The Role of Foreign Technology and Indigenous Innovation in the Emerging Economies: Technological Change and Catching up, World Dev 39, 1204-1212.

Garbaccio, R.F., Ho, M.S., and Jorgenson, D.W. 1999. Why has the energy-output ratio fallen in China? Energy J 20, 63-91

Girma, S., Gong, Y. and Görg, H. 2009. Foreign Direct Investment, Access to Finance, and Innovation Activity in Chinese Enterprises. World Bank Econ Rev 22, 367-382.

Harrison, A. and Rodriguez-Clare 2010. Trade, Foreign Direct Investment and Industrial Policy for Developing Countries. Handbook of Development Economics, vol. 5, Chapter 63, 4039-4198.

Herrerias, MJ. and Orts, V. 2011 Imports and Growth in China, Econ Model 28, 2811-2819

Hübler, M. 2009. Energy Saving Technology Diffusion via FDI and Trade: a CGE Model of China. Kiel Working Papers, No. 1479, January.

Hübler, M. 2011. Technology Diffusion under Contraction and Convergence: A CGE Analysis of China, Energ Econ 33, 131-142.

Hübler, M. and Keller, A. 2010. Energy Savings via FDI? Empirical Evidence from Developing Countries, Environ and Dev Econ 15, 59-80.

International Energy Agency (IEA) 2007 World Energy Outlook 2007. China and India Insights. Available at: http://www.worldenergyoutlook.org/ 
International Energy Agency (IEA) 2010 World Energy Outlook 2010. Available at: http://www.worldenergyoutlook.org/

Ito, T., Chen, Y., Ito, S. and Yamaguchi, K. 2010 Prospect of the upper limit of the energy demand in China from regional aspects, Energ 35, 5320-5327

Keller, W. 2004. International Technology Diffusion. J. Econ Liter XLII, 752-782.

Kugler, M. 2006. Spillovers from Foreign Direct Investment: Within of Between Industries. J. Dev Econ, 80. 444-477.

Kumar, A. 2003. Energy Intensity: A Quantitative Exploration for Indian Manufacturing. Indira Gandhi Institute of Development Research Mumbai-65

Lai, M., Peng, S. and Bao, Q. 2006. Technology spillovers, absorptive capacity and economic growth. China Econ Rev 17, 300-320.

Li K.W. 2009. China's total factor productivity estimates by region, investment sources and ownership. Econ Sys 33, 213-230.

Liao, H., Fan, Y. and Wei, Y. 2007. What induced China's energy intensity to fluctuate: 1997-2006? Energ Policy 35, 4640-4649.

Liu, Z. 2008. Foreign Direct Investment and Technology Spillovers: Theory and Evidence, J. Dev Econ 85, 176-193.

Luo, C. 2007. FDI, Domestic Capital, and Economic Growth: Evidence from Panel Data at China's Provincial Level, Frontiers Econ China 2, 92-113.

Ma, C. and Stern, D. 2008. China's Changing Energy Intensity Trend: a Decomposition Analysis, Energ Econ 30, 1037-1053.

Ma, C, Oxley, L. and Gibson, J. 2010 China's energy economy: A survey of the literature, Econ Sys 34, 105-132

Mielnik, O. and Goldemberg, J. 2002. Foreign Direct Investment and Decoupling Between Energy and Gross Domestic Product in Developing Countries. Energ Policy, 30, 87-89.

Nolan, P. and Wang, X. 1999. Beyond Privatization: Institutional Innovations and Growth in China's Large State-Owned Enterprises, World Dev 27, 169-200.

Parks, R. 1967. Efficient Estimation of a System of Regression Equations When Disturbances Are Both Serially and Contemporaneously Correlated, J. Amer. Stat Assoc 62, 500-509.

Peterson, S. 2008. Greenhouse Gas Mitigation in Developing Countries through Technology Transfer?: A Survey of Empirical Evidence. Mitigation and Adaptation Strategies for Global Change 13, 283-305.

Sahu, S, and Narayanan,K. 2009. Determinants of Energy Intensity: A preliminary investigation of Indian manufacturing. MPRA Paper No. 16606, August

Sinton, J. and Fridley, D. 2000. What Goes Up: Recent Trend in China's Energy Consumption. Energ Policy 28, 671-687.

Wu, K., and Li, B. 1995 Energy Development in China: National policies and regional strategies, Energ Policy 23, 167-178

Yuan, J.H., Kang, J.G., Zhao, C.H., and Hu, Z.G., 2008. Energy consumption and economic growth: evidence from China at both aggregated and disaggregated levels, Energ Econ 30, 3077-3094 
Zhang, Z. 2003. Why did the energy intensity fall in China's industrial sector in the 1990s? The relative importance of structural change and intensity change, Energ Econ 25, 625638

Zhang, J. and Wang, G. 2008: Energy saving technologies and productive efficiency in the Chinese iron and steel sector, Energ 33, 525-537

Zhao, X., Ma, C. and Hong, D. 2010. Why Did China's Energy Intensity Increase During 1998-2006: Decomposition and Policy Analysis. Energ Policy 38, 1379-1388.

Zhou X., Yi, J., Song, R., Yang, X., Li, Y., Tang, H. 2010 An overview of power transmission systems in China, Energ 35, 4302-4312 


\section{Data Appendix}

Energy Intensity (Total EI): Total Energy Consumption / GDP, measured in Million ton SCE Standard Coal Equivalent) and 100 Million Yuan respectively.

Coal Intensity (Coal EI): Coal Consumption / GDP, measured in Million ton and 100 Million Yuan respectively.

Electricity Intensity (Electricity EI): Electricity Intensity / GDP, measured in Terawatthour and 100 Million Yuan respectively.

Petroleum Intensity (Petroleum EI): Petroleum Intensity / GDP, measured in Million ton and 100 Million Yuan respectively.

Share Imports (Imports): Imports/GDP. Imports are measured in dollars, thus we use the exchange rate for each year to transform this variable into local currency. Once this change has been completed, we calculate the ratio over GDP measured in Yuans.

Share Secondary Sector (Industry): Share of the Secondary Sector in the GDP.

Energy Prices (Price): Due data limitations the crude oil price in 2010 dollars has been used as a proxy variable of China's energy prices. Data from BP historical statistics available at: http://www.bp.com/sectionbodycopy.do?categoryId=7500\&contentId=7068481.

\section{Investment by origin:}

Foreign Investment (Foreign): Foreign Direct Investment is measured in dollars, thus we use the exchange rate for each year to transform this variable into local currency. Once this change has been completed, we divide FDI by GDP.

Domestic Investment (Domestic): This is the difference between total investment and FDI as: Total Investment - Foreign Investment) / GDP.

\section{Investment by ownership:}

State-owned Investment (State Investment): This is the investment made by the state sector divided by GDP.

Non-State Investment (Non-State Investment): This is the difference between the total investment and the state investment as: Total Investment - State-owned Investment) / GDP.

\section{Investment in Energy Sector:}

Total State-owned investment in energy sector (State Investment T.): This refers to the total investment made by the State in the total energy sector divided by GDP. 
State-owned investment in electricity (State Investment E.): This refers to the total investment made by the State in electricity divided by GDP.

State-owned investment in coal (State Investment C.): This refers to the total investment made by the State in coal divided by GDP.

State-owned investment in petroleum (State Investment P.): This refers to the total investment made by the State in petroleum divided by GDP.

Total non-state investment in total energy (Non-State Investment T.): This refers to the difference between the total investment in the total energy sector and that made by the State sector divided by GDP.

Non-state investment in electricity (Non-State Investment E.): This refers to the difference between the total investment made in electricity and that made by the State sector divided by GDP.

Non-state investment in coal (Non-State Investment C.): This refers to the difference between the total investment made in coal and that made by the State sector divided by GDP.

Non-state investment in petroleum (Non-State Investment P.): This refers to the difference between the total investment made in petroleum and that made by the State sector divided by GDP.

Note: All data corresponds to the Mainland, and therefore is excluded Hong Hong, Taiwan and Macao.

Transmission Grid, we define a dummy variable for each of the grids as following:

Grid 1: North-East = 1 for Heilongjiang, Jilin, Liaoning and Inner Mongolia;

0 otherwise

Grid 2: North = 1 for Beijing, Tianjin, Hebei, Shanxi and Shandong;

0 otherwise

Grid 3: East = 1 for Shanghai, Zhejiang, Anhui, Jiangsu and Fujian;

0 otherwise

Grid 4: Central = 1 for Jiangxi, Henan, Hubei, Hunan and Sichuan; 0 otherwise

Grid 5: South = 1 for Guangdong, Guangxi, Yunnan and Guizhou; 0 otherwise

Grid 6: North-Western = 1 for Shaanxi, Gansu, Qinghai, Ningxia and Xinjiang; 0 otherwise 
Figure A1: Map of the Transmission grid

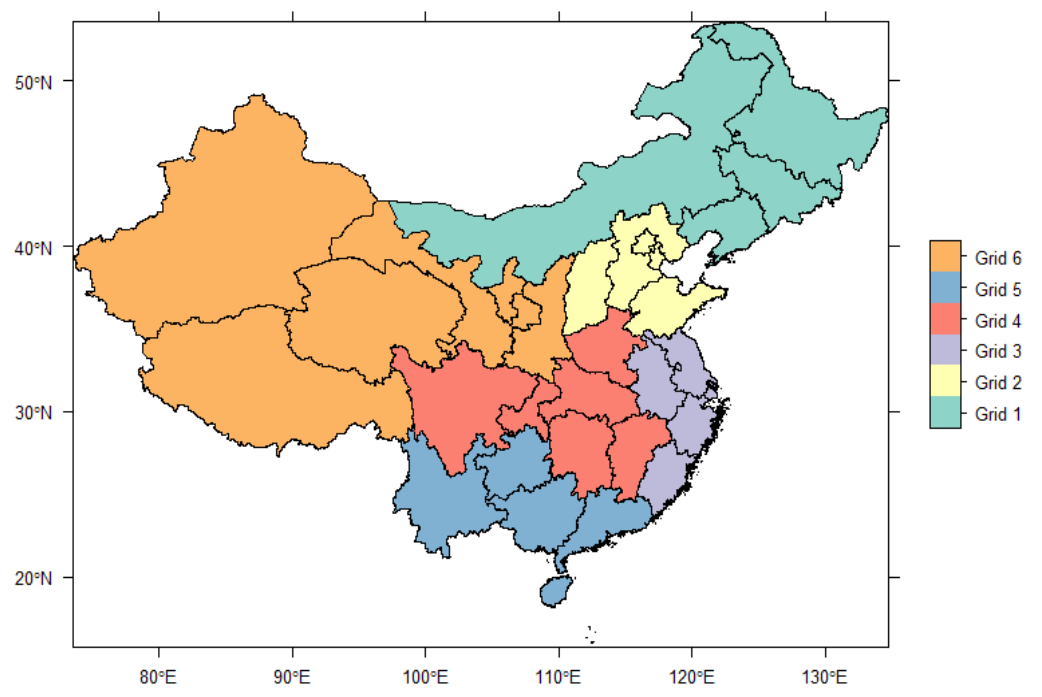

Figure A2: Map of the Administrative Division

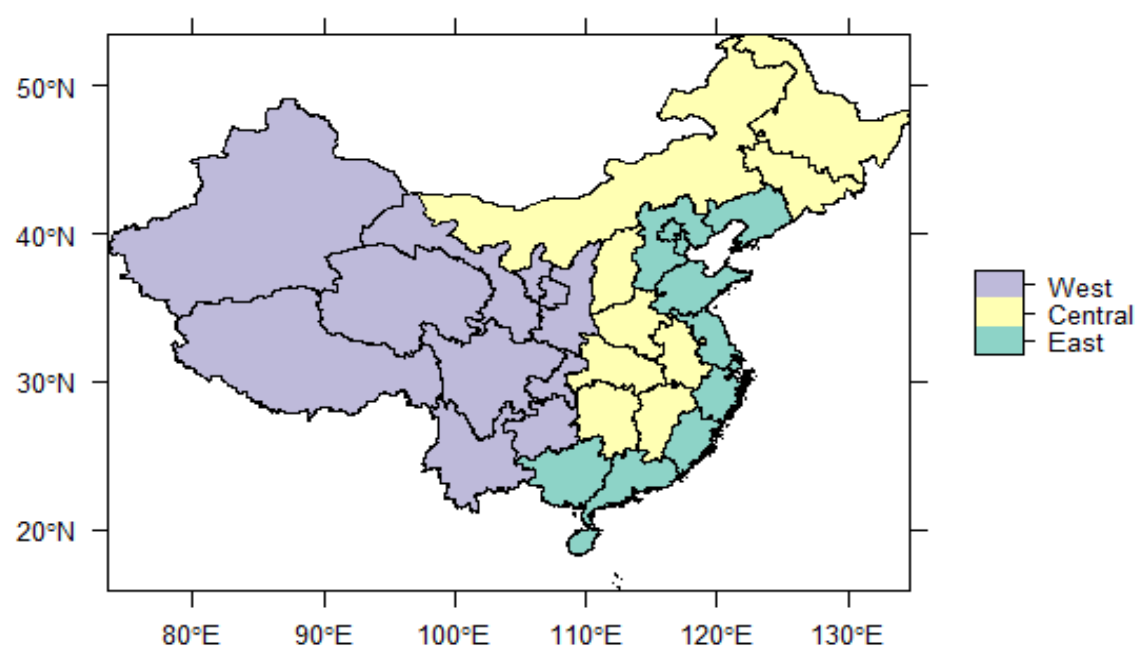

The official partition of the Chinese provinces in three regions is: East provinces: Shanghai, Beijing, Tianjin, Liaoning, Jiangsu, Zhejiang, Guangdong, Shandong, Fujian, Guangxi, Hebei. Central provinces: Heilongjiang, Jilin, Hubei, Shanxi, Hunan, Anhui, Jiangxi, Henan, Inner Mongolia. Western provinces: Sichuan, Xinjiang, Qinghai, Ningxia, Gansu, Shaanxi, Yunnan, Guizhou and Tibet.

Source: Energy Yearbook, various issues, and China Compendium of Statistics 19492008, edited by National Bureau of Statistics of China. 


\section{List of Figures}

Figure 1: Box plot of total energy intensity, coal energy intensity, electricity intensity, and petroleum intensity, 1985, 1995 and 2008.

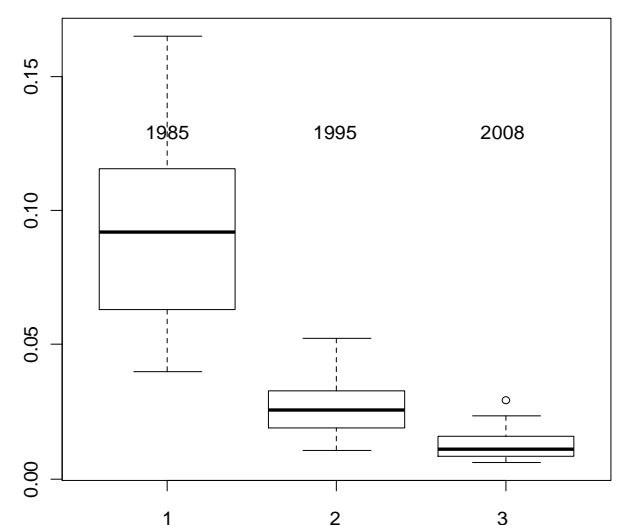

(a) Total energy intensity

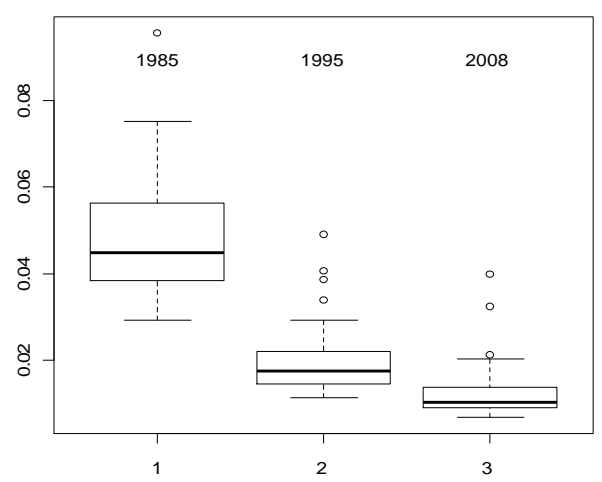

(c)Electricity energy intensity

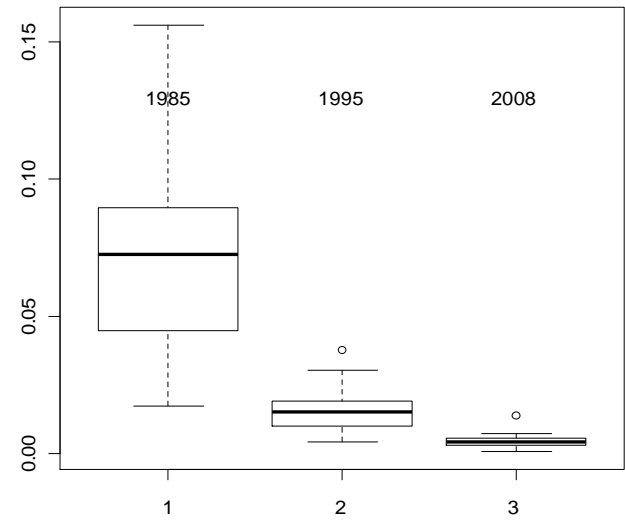

(b) Coal energy intensity

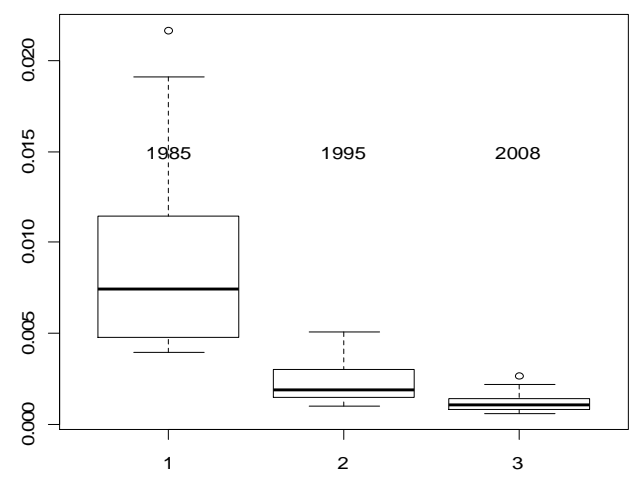

(d) Petroleum energy intensity 
Figure 2: FDI over GDP in the Chinese regions 1995 and 2008

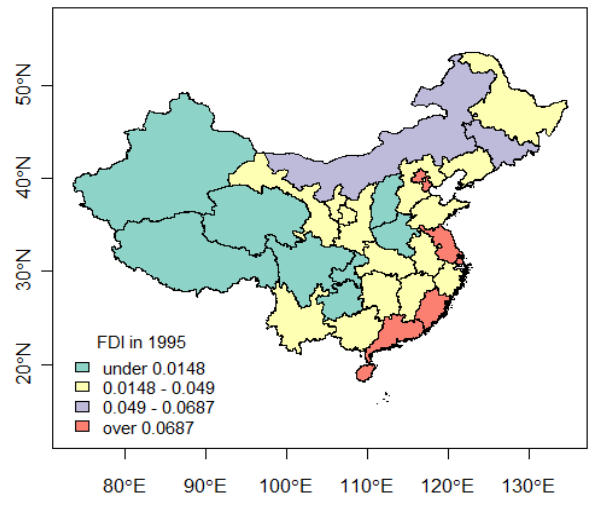

(e) FDI / GDP in 1995

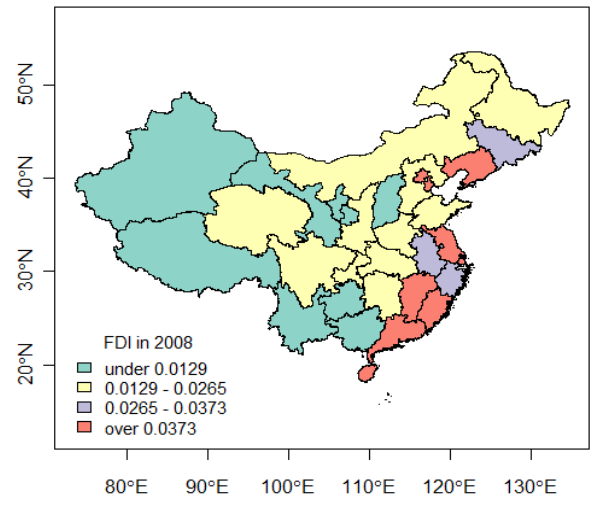

(f) FDI / GDP in 2008

Figure 3: Coal and Electricity intensity in the Chinese regions 1995 and 2008

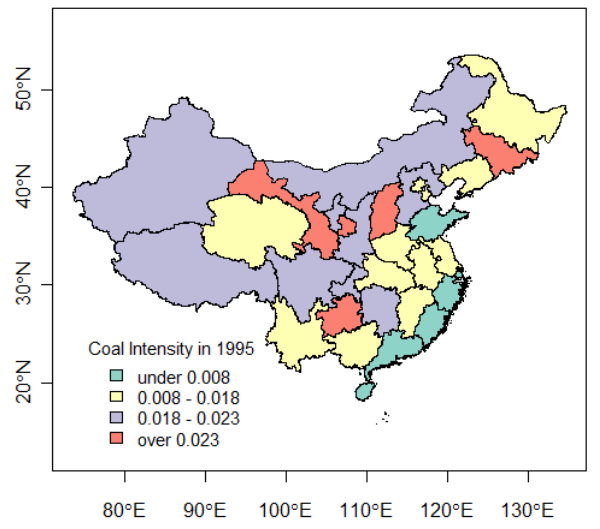

(a) Coal intensity in 1995

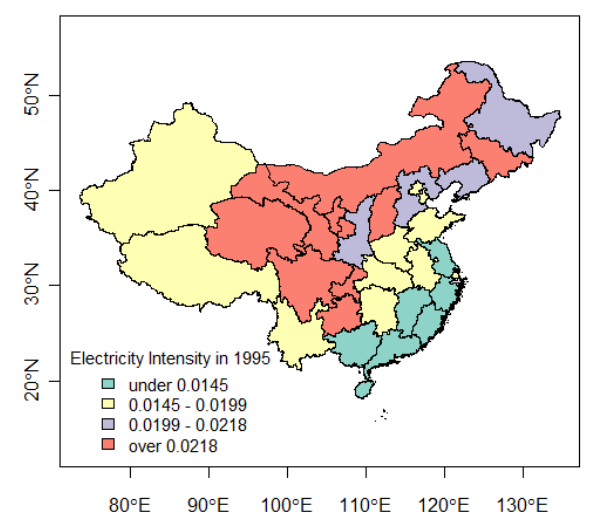

(c) Electricity intensity in 1995

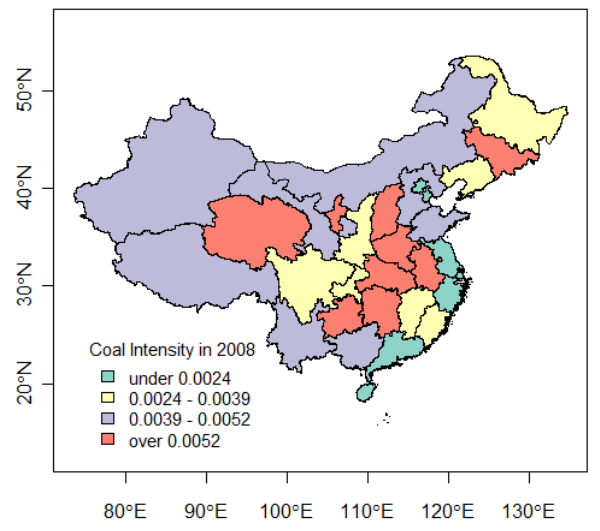

(b)Coal intensity in 2008

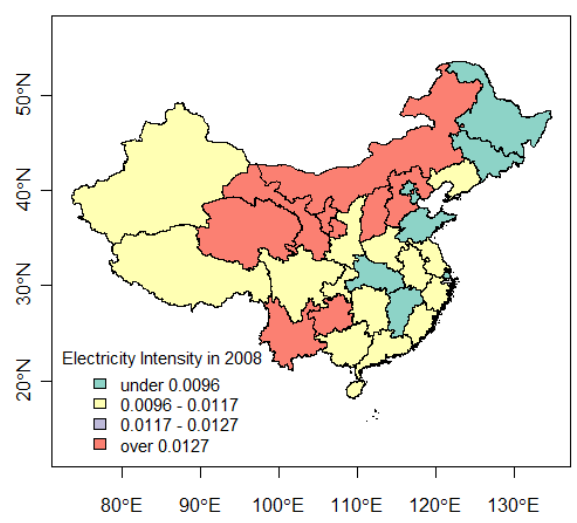

(d) Electricity intensity in 2008 


\section{List of Tables}

Table 1: Descriptive Statistics, Investment Ownership

\begin{tabular}{lcccc}
\hline Variable & Mean & Std. Dev. & Min & Max \\
\hline Foreign Investment & 0.03 & 0.04 & 0.00 & 0.58 \\
Domestic Investment & 0.34 & 0.12 & -0.10 & 0.84 \\
\hline State Investment & 0.08 & 0.03 & 0.02 & 0.23 \\
Non-State Investment & 0.10 & 0.08 & 0.06 & 0.59 \\
\hline Energy State Inv. Total & 0.15 & 0.12 & 0.02 & 0.77 \\
Energy Non-State Inv. Total & 0.002 & 0.02 & -0.05 & 0.17 \\
Energy State Inv. Coal & 0.05 & 0.10 & 0.00 & 0.98 \\
Energy Non-State Inv. Coal & 0.01 & 0.08 & -0.32 & 0.82 \\
Energy State Inv. Petroleum & 0.02 & 0.03 & 0.00 & 0.28 \\
Energy Non-State Inv. Petroleum & 0.01 & 0.06 & -0.10 & 0.68 \\
Energy State Inv. Electricity & 0.09 & 0.08 & 0.01 & 0.55 \\
Energy Non-State Inv. Electricity & 0.002 & 0.01 & -0.05 & 0.32 \\
\hline
\end{tabular}

Note: State and Non-State investment corresponds to the investment by region, while Energy State and Non-State Investment refers to the investment made in energy sector. 
Table 2: Energy Intensity and Investment Ownership by source of energy: Foreign versus Domestic Investment.

\begin{tabular}{|c|c|c|c|c|c|c|c|c|c|c|c|c|}
\hline & Total EI & Total EI & Total EI & Coal EI & Coal EI & Coal EI & Electricity EI & Electricity EI & Electricity EI & Petroleum EI & Petroleum EI & Petroleum EI \\
\hline FDI & $\begin{array}{c}-0.0637^{* * *} \\
(0.022)\end{array}$ & & & $\begin{array}{c}-0.0561^{* * *} \\
(0.019)\end{array}$ & & & $\begin{array}{c}-0.0245^{* *} \\
(0.011)\end{array}$ & & & $\begin{array}{c}-0.00393 \\
(0.003)\end{array}$ & & \\
\hline Domestic investment & $\begin{array}{c}-0.0777^{* * *} \\
(0.009)\end{array}$ & $\begin{array}{c}-0.0810^{* * *} \\
(0.009)\end{array}$ & $\begin{array}{c}-0.0800^{* * *} \\
(0.009)\end{array}$ & $\begin{array}{c}-0.0577^{* * *} \\
(0.008)\end{array}$ & $\begin{array}{c}-0.0600^{* * *} \\
(0.008)\end{array}$ & $\begin{array}{l}-0.0593^{* * *} \\
(0.008)\end{array}$ & $\begin{array}{c}-0.0398^{* * *} \\
(0.005)\end{array}$ & $\begin{array}{c}-0.0411^{* * *} \\
(0.005)\end{array}$ & $\begin{array}{c}-0.0407^{* * *} \\
(0.004)\end{array}$ & $\begin{array}{c}-0.00826^{* * *} \\
(0.001)\end{array}$ & $\begin{array}{c}-0.00845^{* * *} \\
(0.001)\end{array}$ & $\begin{array}{c}-0.00848^{* * *} \\
(0.001)\end{array}$ \\
\hline Industry & $\begin{array}{l}0.0183 \\
(0.017)\end{array}$ & $\begin{array}{l}0.0158 \\
(0.017)\end{array}$ & $\begin{array}{l}0.0190 \\
(0.017)\end{array}$ & $\begin{array}{l}-0.0220 \\
(0.014)\end{array}$ & $\begin{array}{c}-0.0242^{*} \\
(0.014)\end{array}$ & $\begin{array}{l}-0.0217 \\
(0.014)\end{array}$ & $\begin{array}{c}0.0194^{* *} \\
(0.008)\end{array}$ & $\begin{array}{c}0.0185^{* *} \\
(0.008)\end{array}$ & $\begin{array}{c}0.0197^{* *} \\
(0.008)\end{array}$ & $\begin{array}{c}0.0104^{* * *} \\
(0.002)\end{array}$ & $\begin{array}{c}0.0103^{* * *} \\
(0.002)\end{array}$ & $\begin{array}{c}0.0105^{* * *} \\
(0.002)\end{array}$ \\
\hline Imports & $\begin{array}{c}-0.0369^{* * *} \\
(0.008)\end{array}$ & $\begin{array}{c}-0.0334^{* * *} \\
(0.008)\end{array}$ & $\begin{array}{c}-0.0358^{* * *} \\
(0.008)\end{array}$ & $\begin{array}{c}-0.0221^{* * *} \\
(0.007)\end{array}$ & $\begin{array}{c}-0.0194^{* * *} \\
(0.007)\end{array}$ & $\begin{array}{l}-0.0218^{* * *} \\
(0.007)\end{array}$ & $\begin{array}{c}-0.0208^{* * *} \\
(0.004)\end{array}$ & $\begin{array}{c}-0.0194^{* * *} \\
(0.004)\end{array}$ & $\begin{array}{c}-0.0202^{* * *} \\
(0.004)\end{array}$ & $\begin{array}{c}-0.00459^{* * *} \\
(0.001)\end{array}$ & $\begin{array}{c}-0.00451^{* * *} \\
(0.001)\end{array}$ & $\begin{array}{c}-0.00442^{* * *} \\
(0.001)\end{array}$ \\
\hline Price & $\begin{array}{c}-0.0232^{* * *} \\
(0.002)\end{array}$ & $\begin{array}{c}-0.0232^{* * *} \\
(0.002)\end{array}$ & $\begin{array}{c}-0.0235^{* * *} \\
(0.002)\end{array}$ & $\begin{array}{c}-0.0192^{* * *} \\
(0.002)\end{array}$ & $\begin{array}{c}-0.0191^{* * *} \\
(0.002)\end{array}$ & $\begin{array}{l}-0.0193^{* * *} \\
(0.002)\end{array}$ & $\begin{array}{c}-0.0108^{* * *} \\
(0.001)\end{array}$ & $\begin{array}{c}-0.0108^{* * *} \\
(0.001)\end{array}$ & $\begin{array}{c}-0.0109^{* * *} \\
(0.001)\end{array}$ & $\begin{array}{c}-0.00228^{* * *} \\
(0.000)\end{array}$ & $\begin{array}{c}-0.00223^{* * *} \\
(0.000)\end{array}$ & $\begin{array}{c}-0.00233^{* * *} \\
(0.000)\end{array}$ \\
\hline FDI $x$ grid 1 & & $\begin{array}{l}0.0537 \\
(0.091)\end{array}$ & & & $\begin{array}{l}0.0261 \\
(0.078)\end{array}$ & & & $\begin{array}{l}0.0280 \\
(0.044)\end{array}$ & & & $\begin{array}{l}0.0107 \\
(0.011)\end{array}$ & \\
\hline FDI $x$ grid 2 & & $\begin{array}{c}-0.0404^{*} \\
(0.022)\end{array}$ & & & $\begin{array}{c}-0.0346^{*} \\
(0.019)\end{array}$ & & & $\begin{array}{l}-0.0151 \\
(0.010)\end{array}$ & & & $\begin{array}{c}-0.00614^{*} \\
(0.004)\end{array}$ & \\
\hline FDI $x$ grid 3 & & $\begin{array}{c}-0.0647^{* *} \\
(0.027)\end{array}$ & & & $\begin{array}{c}-0.0574^{* *} \\
(0.024)\end{array}$ & & & $\begin{array}{c}-0.0233^{*} \\
(0.013)\end{array}$ & & & $\begin{array}{c}-0.00702^{* *} \\
(0.003)\end{array}$ & \\
\hline FDI $x$ grid 4 & & $\begin{array}{l}-0.0843 \\
(0.091)\end{array}$ & & & $\begin{array}{l}-0.0889 \\
(0.079)\end{array}$ & & & $\begin{array}{l}-0.0308 \\
(0.044)\end{array}$ & & & $\begin{array}{c}-0.00903 \\
(0.010)\end{array}$ & \\
\hline FDI $x$ grid 5 & & $\begin{array}{c}-0.152^{* * *} \\
(0.038)\end{array}$ & & & $\begin{array}{c}-0.134^{* * *} \\
(0.035)\end{array}$ & & & $\begin{array}{c}-0.0638^{* * *} \\
(0.020)\end{array}$ & & & $\begin{array}{c}-0.0101^{*} \\
(0.005)\end{array}$ & \\
\hline FDI $x$ grid 6 & & $\begin{array}{c}-0.472^{* * *} \\
(0.181)\end{array}$ & & & $\begin{array}{l}-0.279 \\
(0.180)\end{array}$ & & & $\begin{array}{l}-0.205^{*} \\
(0.123)\end{array}$ & & & $\begin{array}{l}-0.0121 \\
(0.011)\end{array}$ & \\
\hline FDI $x$ east & & & $\begin{array}{c}-0.0567^{* * *} \\
(0.022)\end{array}$ & & & $\begin{array}{l}-0.0545^{* * *} \\
(0.019)\end{array}$ & & & $\begin{array}{c}-0.0200^{*} \\
(0.011)\end{array}$ & & & $\begin{array}{c}-0.00287 \\
(0.003)\end{array}$ \\
\hline FDI $x$ center & & & $\begin{array}{l}-0.0417 \\
(0.080)\end{array}$ & & & $\begin{array}{l}-0.0216 \\
(0.074)\end{array}$ & & & $\begin{array}{l}-0.0246 \\
(0.037)\end{array}$ & & & $\begin{array}{c}-0.00446 \\
(0.008)\end{array}$ \\
\hline
\end{tabular}




\begin{tabular}{|c|c|c|c|c|c|c|c|c|c|c|c|c|}
\hline FDI $x$ western & & & $\begin{array}{c}-0.428^{* * *} \\
(0.157)\end{array}$ & & & $\begin{array}{l}0.259^{*} \\
0.152)\end{array}$ & & & $\begin{array}{l}-0.194^{*} \\
(0.102) \\
\end{array}$ & & & $\begin{array}{c}-0.0441^{* *} \\
(0.019) \\
\end{array}$ \\
\hline No Observations & 448 & 448 & 448 & 448 & 448 & 448 & 448 & 448 & 448 & 448 & 448 & 448 \\
\hline $\mathrm{R}^{2}$ & 0.6947 & 0.7082 & 0.7006 & 0.6376 & 0.6482 & 0.6406 & 0.7763 & 0.7845 & 0.7808 & 0.6072 & 0.6168 & 0.6134 \\
\hline Time effects & Yes & Yes & Yes & Yes & Yes & Yes & Yes & Yes & Yes & Yes & Yes & Yes \\
\hline Individual Effects & Yes & Yes & Yes & Yes & Yes & Yes & Yes & Yes & Yes & Yes & Yes & Yes \\
\hline
\end{tabular}


Table 3: Energy Intensity and Investment Ownership by source of energy: State vs Non-State Investment

\begin{tabular}{|c|c|c|c|c|c|c|c|c|c|c|c|c|}
\hline & Total EI & Total EI & Total EI & Coal EI & Coal EI & Coal EI & Electricity EI & Electricity EI & Electricity EI & Petroleum EI & Petroleum EI & Petroleum EI \\
\hline State-Investment & $\begin{array}{c}0.0152^{* * *} \\
(0.002)\end{array}$ & & & $\begin{array}{c}0.0133^{* * *} \\
(0.002)\end{array}$ & & & $\begin{array}{c}0.00719^{* * *} \\
(0.001)\end{array}$ & & & $\begin{array}{c}0.00200^{* * *} \\
(0.000)\end{array}$ & & \\
\hline Non-state investment & $\begin{array}{c}-0.00290^{*} \\
(0.002)\end{array}$ & & & $\begin{array}{c}-0.00414^{* * *} \\
(0.001)\end{array}$ & & & $\begin{array}{c}0.000290 \\
(0.001)\end{array}$ & & & $\begin{array}{c}-0.000455^{* *} \\
(0.000)\end{array}$ & & \\
\hline Industry & $\begin{array}{c}0.0593^{* * *} \\
(0.022)\end{array}$ & $\begin{array}{c}0.0326^{* *} \\
(0.013)\end{array}$ & $\begin{array}{c}0.0522^{* *} \\
(0.021)\end{array}$ & $\begin{array}{c}0.00483 \\
(0.021)\end{array}$ & $\begin{array}{c}-0.0308^{* *} \\
(0.015)\end{array}$ & $\begin{array}{c}-0.0000582 \\
(0.020)\end{array}$ & $\begin{array}{c}0.0388^{* * *} \\
(0.011)\end{array}$ & $\begin{array}{c}0.0290^{* * *} \\
(0.008)\end{array}$ & $\begin{array}{c}0.0316^{* * *} \\
(0.010)\end{array}$ & $\begin{array}{c}0.0169^{* * *} \\
(0.002)\end{array}$ & $\begin{array}{c}0.0207^{* * *} \\
(0.003)\end{array}$ & $\begin{array}{c}0.0196^{* * *} \\
(0.003)\end{array}$ \\
\hline Imports & $\begin{array}{c}-0.000103 \\
(0.017)\end{array}$ & $\begin{array}{c}0.0144^{*} \\
(0.008)\end{array}$ & $\begin{array}{c}-0.00929 \\
(0.015)\end{array}$ & $\begin{array}{c}0.00832 \\
(0.016)\end{array}$ & $\begin{array}{c}0.0201^{* *} \\
(0.009)\end{array}$ & $\begin{array}{c}-0.0000691 \\
(0.013)\end{array}$ & $\begin{array}{c}-0.00620 \\
(0.008)\end{array}$ & $\begin{array}{c}0.00197 \\
(0.004)\end{array}$ & $\begin{array}{c}-0.0108 \\
(0.007)\end{array}$ & $\begin{array}{c}-0.00177 \\
(0.002)\end{array}$ & $\begin{array}{c}-0.00268 \\
(0.003)\end{array}$ & $\begin{array}{c}0.000826 \\
(0.002)\end{array}$ \\
\hline Price & $\begin{array}{c}-0.0290^{* * *} \\
(0.003)\end{array}$ & $\begin{array}{c}-0.0434^{* * *} \\
(0.002)\end{array}$ & $\begin{array}{c}-0.0268^{* * *} \\
(0.003)\end{array}$ & $\begin{array}{c}-0.0226^{* * *} \\
(0.003)\end{array}$ & $\begin{array}{c}-0.0342^{* * *} \\
(0.002)\end{array}$ & $\begin{array}{c}-0.0205^{* * *} \\
(0.003)\end{array}$ & $\begin{array}{c}-0.0125^{* * *} \\
(0.002)\end{array}$ & $\begin{array}{c}-0.0223^{* * *} \\
(0.001)\end{array}$ & $\begin{array}{c}-0.0141^{* * *} \\
(0.002)\end{array}$ & $\begin{array}{c}-0.00257^{* * *} \\
(0.000)\end{array}$ & $\begin{array}{c}-0.00353^{* * *} \\
(0.000)\end{array}$ & $\begin{array}{c}-0.00341^{* * *} \\
(0.001)\end{array}$ \\
\hline State-inv $x$ grid 1 & & $\begin{array}{c}0.0135^{* * *} \\
(0.003)\end{array}$ & & & $\begin{array}{c}0.0117^{* * *} \\
(0.003)\end{array}$ & & & $\begin{array}{c}0.00296 \\
(0.002)\end{array}$ & & & $\begin{array}{c}0.00231^{* * *} \\
(0.001)\end{array}$ & \\
\hline Non-state inv $\mathrm{x}$ grid 1 & & $\begin{array}{c}-0.00806^{* * *} \\
(0.002)\end{array}$ & & & $\begin{array}{c}-0.00763^{* * *} \\
(0.003)\end{array}$ & & & $\begin{array}{c}-0.00191 \\
(0.001)\end{array}$ & & & $\begin{array}{c}-0.000300 \\
(0.001)\end{array}$ & \\
\hline State-inv $x$ grid 2 & & $\begin{array}{c}0.0148^{* * *} \\
(0.004)\end{array}$ & & & $\begin{array}{c}0.0171^{* * *} \\
(0.005)\end{array}$ & & & $\begin{array}{c}0.00184 \\
(0.002)\end{array}$ & & & $\begin{array}{c}0.00132^{* * *} \\
(0.001)\end{array}$ & \\
\hline Non-state inv $\mathrm{x}$ grid 2 & & $\begin{array}{c}-0.00696^{* * *} \\
(0.002)\end{array}$ & & & $\begin{array}{c}-0.00895^{* * *} \\
(0.003)\end{array}$ & & & $\begin{array}{c}-0.00108 \\
(0.001)\end{array}$ & & & $\begin{array}{c}0.0000633 \\
(0.000)\end{array}$ & \\
\hline State-inv $x$ grid 3 & & $\begin{array}{c}-0.0152^{* * *} \\
(0.003)\end{array}$ & & & $\begin{array}{c}-0.0136^{* * *} \\
(0.004)\end{array}$ & & & $\begin{array}{c}-0.00602^{* * *} \\
(0.002)\end{array}$ & & & $\begin{array}{c}-0.000683 \\
(0.001)\end{array}$ & \\
\hline Non-state inv $\mathrm{x}$ grid 3 & & $\begin{array}{c}0.00274 \\
(0.002)\end{array}$ & & & $\begin{array}{c}0.00257 \\
(0.002)\end{array}$ & & & $\begin{array}{c}0.00129 \\
(0.001)\end{array}$ & & & $\begin{array}{c}0.000513 \\
(0.000)\end{array}$ & \\
\hline State-inv $x$ grid 4 & & $\begin{array}{c}-0.000218 \\
(0.003)\end{array}$ & & & $\begin{array}{c}-0.00177 \\
(0.003)\end{array}$ & & & $\begin{array}{c}-0.00138 \\
(0.002)\end{array}$ & & & $\begin{array}{c}0.000825 \\
(0.001)\end{array}$ & \\
\hline Non-state inv $\mathrm{x}$ grid 4 & & $\begin{array}{c}-0.00209 \\
(0.002)\end{array}$ & & & $\begin{array}{c}-0.00179 \\
(0.002)\end{array}$ & & & $\begin{array}{c}0.000282 \\
(0.001)\end{array}$ & & & $\begin{array}{c}0.000166 \\
(0.000)\end{array}$ & \\
\hline State-inv $x$ grid 5 & & $\begin{array}{c}-0.00213 \\
(0.002)\end{array}$ & & & $\begin{array}{c}-0.00152 \\
(0.002)\end{array}$ & & & $\begin{array}{c}-0.00256^{* * *} \\
(0.001)\end{array}$ & & & $\begin{array}{c}-0.000283 \\
(0.000)\end{array}$ & \\
\hline
\end{tabular}




\begin{tabular}{|c|c|c|c|c|c|c|c|c|c|c|c|c|}
\hline Non-state inv $\mathrm{x}$ grid 5 & \multicolumn{3}{|c|}{$\begin{array}{c}-0.00562^{* * *} \\
(0.002)\end{array}$} & \multicolumn{3}{|c|}{$\begin{array}{c}-0.00599 * * * \\
(0.002)\end{array}$} & \multicolumn{3}{|c|}{$\begin{array}{c}-0.00166^{* *} \\
(0.001)\end{array}$} & \multicolumn{3}{|c|}{$\begin{array}{c}0.00112^{* * *} \\
(0.000)\end{array}$} \\
\hline \multirow[t]{2}{*}{ State-inv $x$ grid 6} & & $0.00433^{* * *}$ & & & $0.00546^{* * *}$ & & & -0.00124 & & & $0.00258^{* * *}$ & \\
\hline & & $(0.002)$ & & & $(0.001)$ & & & $(0.001)$ & & & $(0.000)$ & \\
\hline \multirow[t]{2}{*}{ Non-state inv $x$ grid 6} & & $-0.00418^{* *}$ & & & $-0.00557^{* * *}$ & & & 0.00192 & & & $-0.000638^{*}$ & \\
\hline & & $(0.002)$ & & & $(0.002)$ & & & $(0.001)$ & & & $(0.000)$ & \\
\hline State-inv $\mathrm{x}$ east & & & $\begin{array}{c}0.00923^{* *} \\
(0.004)\end{array}$ & & & $\begin{array}{c}0.00709^{*} \\
(0.004)\end{array}$ & & & $\begin{array}{c}0.00389^{*} \\
(0.002)\end{array}$ & & & $\begin{array}{c}0.00121^{* *} \\
(0.000)\end{array}$ \\
\hline Non-state inv $\mathrm{x}$ east & & & $\begin{array}{c}0.000144 \\
(0.002)\end{array}$ & & & $\begin{array}{c}-0.000707 \\
(0.002)\end{array}$ & & & $\begin{array}{c}0.00102 \\
(0.001)\end{array}$ & & & $\begin{array}{c}-0.000128 \\
(0.000)\end{array}$ \\
\hline State-inv $\mathrm{x}$ center & & & $\begin{array}{c}0.0253^{* * *} \\
(0.005)\end{array}$ & & & $\begin{array}{c}0.0223^{* * *} \\
(0.005)\end{array}$ & & & $\begin{array}{c}0.00944^{* * * *} \\
(0.002)\end{array}$ & & & $\begin{array}{c}0.00119^{* *} \\
(0.001)\end{array}$ \\
\hline Non-state inv $\mathrm{x}$ center & & & $\begin{array}{c}-0.00816^{* *} \\
(0.004)\end{array}$ & & & $\begin{array}{c}-0.00911^{* *} \\
(0.004)\end{array}$ & & & $\begin{array}{c}-0.000958 \\
(0.002)\end{array}$ & & & $\begin{array}{c}-0.000206 \\
(0.000)\end{array}$ \\
\hline State-inv $\mathrm{x}$ west & & & $\begin{array}{c}0.0163^{* * *} \\
(0.002)\end{array}$ & & & $\begin{array}{c}0.0150^{* * *} \\
(0.002)\end{array}$ & & & $\begin{array}{l}0.00457^{* * *} \\
(0.001)\end{array}$ & & & $\begin{array}{l}0.00160^{* * *} \\
(0.000)\end{array}$ \\
\hline Non-state inv $x$ west & & & $\begin{array}{c}-0.00406^{*} \\
(0.002) \\
\end{array}$ & & & $\begin{array}{c}-0.00605^{* * *} \\
(0.002) \\
\end{array}$ & & & $\begin{array}{c}0.00217 \\
(0.001) \\
\end{array}$ & & & $\begin{array}{c}-0.000508 \\
(0.000) \\
\end{array}$ \\
\hline No Observations & 140 & 140 & 140 & 140 & 140 & 140 & 140 & 140 & 140 & 140 & 140 & 140 \\
\hline $\mathrm{R}^{2}$ & 0.8533 & 0.9707 & 0.8669 & 0.8209 & 0.9432 & 0.8365 & 0.8404 & 0.9523 & 0.8660 & 0.8096 & 0.8637 & 0.8384 \\
\hline Time effects & Yes & Yes & Yes & Yes & Yes & Yes & Yes & Yes & Yes & Yes & Yes & Yes \\
\hline Individual Effects & Yes & Yes & Yes & Yes & Yes & Yes & Yes & Yes & Yes & Yes & Yes & Yes \\
\hline
\end{tabular}

Standard errors in parentheses. ${ }^{*} \mathrm{p}<.10,{ }^{* *} \mathrm{p}<.05,{ }^{* * *} \mathrm{p}<.01$ 
Table 4: Energy Intensity and Investment Ownership by source of energy: State vs. Non-State Energy Investment

\begin{tabular}{|c|c|c|c|c|c|c|c|c|c|c|c|c|}
\hline & Total EI & Total EI & Total EI & Coal EI & Coal EI & Coal EI & Electricity EI & Electricity EI & Electricity EI & Petroleum EI & Petroleum EI & Petroleum EI \\
\hline State Energy Investment & $\begin{array}{c}0.00824 \\
(0.006)\end{array}$ & & & $\begin{array}{c}0.0755^{* *} \\
(0.034)\end{array}$ & & & $\begin{array}{c}-0.0105^{*} \\
(0.006)\end{array}$ & & & $\begin{array}{c}0.0353^{* * *} \\
(0.009)\end{array}$ & & \\
\hline Non-state Energy Investment & $\begin{array}{c}-0.0471^{* * *} \\
(0.006)\end{array}$ & & & $\begin{array}{c}-0.110^{* * *} \\
(0.033)\end{array}$ & & & $\begin{array}{c}-0.0319^{* * *} \\
(0.006)\end{array}$ & & & $\begin{array}{c}-0.0307^{* * *} \\
(0.009)\end{array}$ & & \\
\hline Imports & $\begin{array}{c}-0.0183^{*} \\
(0.011)\end{array}$ & $\begin{array}{l}-0.0168 \\
(0.010)\end{array}$ & $\begin{array}{l}-0.0135 \\
(0.010)\end{array}$ & $\begin{array}{l}0.0116 \\
(0.013)\end{array}$ & $\begin{array}{c}-0.000359 \\
(0.012)\end{array}$ & $\begin{array}{l}0.0124 \\
(0.012)\end{array}$ & $\begin{array}{c}-0.0143^{* * *} \\
(0.005)\end{array}$ & $\begin{array}{c}-0.00732 \\
(0.004)\end{array}$ & $\begin{array}{c}-0.0131^{* * *} \\
(0.005)\end{array}$ & $\begin{array}{c}-0.00431^{* * *} \\
(0.001)\end{array}$ & $\begin{array}{c}-0.00241^{*} \\
(0.001)\end{array}$ & $\begin{array}{c}-0.00433^{* * *} \\
(0.001)\end{array}$ \\
\hline Industry & $\begin{array}{l}0.0126 \\
(0.015)\end{array}$ & $\begin{array}{l}0.0155 \\
(0.015)\end{array}$ & $\begin{array}{r}0.00651 \\
(0.014)\end{array}$ & $\begin{array}{c}-0.0542^{* * *} \\
(0.015)\end{array}$ & $\begin{array}{c}-0.0320^{* *} \\
(0.015)\end{array}$ & $\begin{array}{c}-0.0488^{* * *} \\
(0.014)\end{array}$ & $\begin{array}{c}0.000570 \\
(0.008)\end{array}$ & $\begin{array}{c}0.0175^{* *} \\
(0.008)\end{array}$ & $\begin{array}{c}0.00623 \\
(0.007)\end{array}$ & $\begin{array}{c}0.00810^{* * *} \\
(0.002)\end{array}$ & $\begin{array}{c}0.0145^{* * *} \\
(0.002)\end{array}$ & $\begin{array}{c}0.00848^{* * *} \\
(0.002)\end{array}$ \\
\hline Price & $\begin{array}{c}-0.00354^{*} \\
(0.002)\end{array}$ & $\begin{array}{c}-0.00517^{* *} \\
(0.002)\end{array}$ & $\begin{array}{c}-0.00488^{*} \\
(0.003)\end{array}$ & $\begin{array}{c}-0.00723^{* * *} \\
(0.003)\end{array}$ & $\begin{array}{c}-0.00440^{*} \\
(0.002)\end{array}$ & $\begin{array}{c}-0.00467^{*} \\
(0.003)\end{array}$ & $\begin{array}{c}-0.00443^{* * *} \\
(0.001)\end{array}$ & $\begin{array}{c}-0.00219^{*} \\
(0.001)\end{array}$ & $\begin{array}{c}-0.00346^{* *} \\
(0.001)\end{array}$ & $\begin{array}{c}-0.000834^{* *} \\
(0.000)\end{array}$ & $\begin{array}{c}-0.00137^{* * *} \\
(0.000)\end{array}$ & $\begin{array}{c}-0.000707^{*} \\
(0.000)\end{array}$ \\
\hline State Energy Inv. $x$ grid 1 & & $\begin{array}{c}0.0347^{* *} \\
(0.014)\end{array}$ & & & $\begin{array}{c}0.636^{* * *} \\
(0.142)\end{array}$ & & & $\begin{array}{l}0.0245^{*} \\
(0.014)\end{array}$ & & & $\begin{array}{l}0.0335^{*} \\
(0.019)\end{array}$ & \\
\hline Non-state Energy Inv. $x$ grid 1 & & $\begin{array}{c}-0.0532^{* * *} \\
(0.010)\end{array}$ & & & $\begin{array}{c}-0.165^{* * *} \\
(0.053)\end{array}$ & & & $\begin{array}{c}-0.0407^{* * *} \\
(0.012)\end{array}$ & & & $\begin{array}{c}-0.0488^{* * *} \\
(0.010)\end{array}$ & \\
\hline State Energy Inv $x$ grid 2 & & $\begin{array}{c}0.0399^{* * *} \\
(0.011)\end{array}$ & & & $\begin{array}{c}0.165^{* * *} \\
(0.059)\end{array}$ & & & $\begin{array}{c}0.0269^{* * *} \\
(0.006)\end{array}$ & & & $\begin{array}{c}-0.000879 \\
(0.014)\end{array}$ & \\
\hline Non-state Energy Inv. $x$ grid 2 & & $\begin{array}{c}-0.0769^{* * *} \\
(0.014)\end{array}$ & & & $\begin{array}{l}-0.0838 \\
(0.057)\end{array}$ & & & $\begin{array}{c}-0.0808^{* * *} \\
(0.008)\end{array}$ & & & $\begin{array}{c}-0.0422^{* * *} \\
(0.013)\end{array}$ & \\
\hline State Energy Inv $x$ grid 3 & & $\begin{array}{c}-0.0469^{* * *} \\
(0.010)\end{array}$ & & & $\begin{array}{c}-0.146^{* * *} \\
(0.042)\end{array}$ & & & $\begin{array}{c}-0.00960 \\
(0.007)\end{array}$ & & & $\begin{array}{c}-0.0296^{* *} \\
(0.012)\end{array}$ & \\
\hline Non-state Energy Inv. $x$ grid 3 & & $\begin{array}{c}-0.0976^{* * *} \\
(0.007)\end{array}$ & & & $\begin{array}{c}-0.135^{* * *} \\
(0.045)\end{array}$ & & & $\begin{array}{c}-0.0514^{* * *} \\
(0.006)\end{array}$ & & & $\begin{array}{c}-0.0315^{* * *} \\
(0.009)\end{array}$ & \\
\hline State Energy Inv $x$ grid 4 & & $\begin{array}{l}0.0131 \\
(0.011)\end{array}$ & & & $\begin{array}{c}0.202^{* * *} \\
(0.064)\end{array}$ & & & $\begin{array}{c}0.00430 \\
(0.007)\end{array}$ & & & $\begin{array}{c}-0.0820^{* * *} \\
(0.023)\end{array}$ & \\
\hline Non-state Energy Inv. $x$ grid 4 & & $\begin{array}{c}-0.0738^{* * *} \\
(0.011)\end{array}$ & & & $\begin{array}{c}-0.146^{* *} \\
(0.059)\end{array}$ & & & $\begin{array}{c}-0.0441^{* * *} \\
(0.007)\end{array}$ & & & $\begin{array}{c}-0.148^{* * *} \\
(0.031)\end{array}$ & \\
\hline State Energy Inv $x$ grid 5 & & $\begin{array}{r}-0.0110 \\
(0.007)\end{array}$ & & & $\begin{array}{l}0.0521 \\
(0.046)\end{array}$ & & & $\begin{array}{c}-0.0129^{* *} \\
(0.006)\end{array}$ & & & $\begin{array}{c}0.00676 \\
(0.016)\end{array}$ & \\
\hline Non-state Energy Inv. x grid 5 & & $-0.0351^{* * *}$ & & & $-0.167^{* * *}$ & & & $-0.0199^{* * *}$ & & & -0.0218 & \\
\hline
\end{tabular}




\begin{tabular}{|c|c|c|c|c|c|c|c|c|c|c|c|c|}
\hline & & $(0.006)$ & & & $(0.039)$ & & & $(0.005)$ & & & $(0.018)$ & \\
\hline State Energy Inv x grid 6 & & $\begin{array}{c}0.00714 \\
(0.005)\end{array}$ & & & $\begin{array}{l}0.0306 \\
(0.040)\end{array}$ & & & $\begin{array}{c}0.00132 \\
(0.008)\end{array}$ & & & $\begin{array}{c}0.0388^{* * *} \\
(0.011)\end{array}$ & \\
\hline Non-state Energy Inv. $x$ grid 6 & & $\begin{array}{c}-0.0479^{* * *} \\
(0.007)\end{array}$ & & & $\begin{array}{c}-0.338^{* * *} \\
(0.060)\end{array}$ & & & $\begin{array}{c}-0.0664^{* * *} \\
(0.011)\end{array}$ & & & $\begin{array}{c}-0.0249^{*} \\
(0.013)\end{array}$ & \\
\hline State Energy Inv $x$ east & & & $\begin{array}{c}-0.00656 \\
(0.011)\end{array}$ & & & $\begin{array}{c}-0.188^{* *} \\
(0.088)\end{array}$ & & & $\begin{array}{c}-0.00752 \\
(0.008)\end{array}$ & & & $\begin{array}{c}0.0203^{*} \\
(0.011)\end{array}$ \\
\hline Non-state Energy Inv. $x$ east & & & $\begin{array}{c}-0.0604^{* * *} \\
(0.011)\end{array}$ & & & $\begin{array}{c}-0.486^{* * *} \\
(0.114)\end{array}$ & & & $\begin{array}{c}-0.0487^{* * *} \\
(0.007)\end{array}$ & & & $\begin{array}{c}-0.0435^{* * *} \\
(0.009)\end{array}$ \\
\hline State Energy Inv $x$ centre & & & $\begin{array}{c}0.0247^{* * *} \\
(0.009)\end{array}$ & & & $\begin{array}{c}0.124^{* * *} \\
(0.046)\end{array}$ & & & $\begin{array}{c}0.00367 \\
(0.007)\end{array}$ & & & $\begin{array}{l}0.0101 \\
(0.014)\end{array}$ \\
\hline Non-state Energy Inv. $x$ center & & & $\begin{array}{c}-0.0481^{* * *} \\
(0.009)\end{array}$ & & & $\begin{array}{c}-0.0705^{* *} \\
(0.035)\end{array}$ & & & $\begin{array}{c}-0.0423^{* * *} \\
(0.007)\end{array}$ & & & $\begin{array}{c}-0.0349^{* * *} \\
(0.010)\end{array}$ \\
\hline State Energy Inv $x$ west & & & $\begin{array}{c}0.00636 \\
(0.005)\end{array}$ & & & $\begin{array}{l}0.0354 \\
(0.037)\end{array}$ & & & $\begin{array}{c}-0.0124^{*} \\
(0.006)\end{array}$ & & & $\begin{array}{c}0.0454^{* * *} \\
(0.012)\end{array}$ \\
\hline Non-state Energy Inv. $x$ west & & & $\begin{array}{c}-0.0289^{* * *} \\
(0.005)\end{array}$ & & & $\begin{array}{c}-0.250^{* * *} \\
(0.042)\end{array}$ & & & $\begin{array}{c}-0.0279^{* * *} \\
(0.006)\end{array}$ & & & $\begin{array}{c}-0.0226 \\
(0.014) \\
\end{array}$ \\
\hline No Observations & 280 & 280 & 280 & 258 & 258 & 258 & 280 & 280 & 280 & 258 & 258 & 258 \\
\hline $\mathrm{R}^{2}$ & 0.8383 & 0.8789 & 0.8680 & 0.8239 & 0.8661 & 0.8378 & 0.8267 & 0.8718 & 0.8357 & 0.7662 & 0.8156 & 0.7720 \\
\hline Time effects & Yes & Yes & Yes & Yes & Yes & Yes & Yes & Yes & Yes & Yes & Yes & Yes \\
\hline Individual Effects & Yes & Yes & Yes & Yes & Yes & Yes & Yes & Yes & Yes & Yes & Yes & Yes \\
\hline
\end{tabular}

Standard errors in parentheses. ${ }^{*} \mathrm{p}<.10,{ }^{* *} \mathrm{p}<.05,{ }^{* * *} \mathrm{p}<.01$ 